\title{
Pengaruh NPF, FDR, dan BOPO terhadap tingkat bagi Hasil deposito mudharabah: ROA sebagai variabel moderating
}

\author{
Aninda Eva Riri Indah Damayanti ${ }^{1^{*}}$, Arna Asna Annisa ${ }^{1}$ \\ ${ }^{1}$ Fakultas Ekonomi dan Bisnis Islam IAIN Salatiga, Indonesia \\ $\left.{ }^{*}\right)$ Korespondensi (e-mail: anindaeva1@gmail.com) \\ Received: 29 - Maret -2021; Revised: 15 - April-2021; Accepted: 29-April-2021
}

\begin{abstract}
This study aims to analyze the effect of non-performing financing, financing to deposit ratio, and operational costs and operational income on the profit-sharing rate of mudharabah deposits with return on asset as a moderating variable. This research is quan titative research with data panels. The population in this study was 14 Islamic Commercial Bank in Indonesia for the period 2015-2019. The sample selection used the purposive sampling method. The analysis technique used is multiple linear regression analysis. The results found that nonperforming financing and operational costs and operational income have a neg ative effect on the profit-sharing rate of mudharabah deposits. However, the financing to deposit ratio has a positive effect on the profit-sharing rate of mudharabah deposits. Return on assets does not moderate the non-performing financing and financing to deposit ratio variable but does moderate operational costs and operational income variable on the profit-sharing rate of mudharabah deposits.
\end{abstract}

Keywords: Non-Performing Financing, Financing to Deposit Ratio, Operational Costs and Operational Income, Mudh arabah Deposit Profit Sharing Rate, Return on Assets

\begin{abstract}
Abstrak
Penelitian ini bertujuan untuk menganalisis pengaruh non-performing financing, financing to deposit ratio, dan biaya operasonal dan pendapatan operasional terhadap tingkat bagi hasil deposito mudharabah dengan return on asset sebagai variabel moderasi. Jenis penelitian ini ad alah penelitian kuantitatif dengan data sekunder berbentuk panel. populasid alam penelitian ini adalah 14 bank umum syariah di indonesia periode 2015-2019. Pemilihan sampel menggunakan metode purposive sampling. teknik analisis yang digunakan adalah analisis regresi linier berg anda. Hasil pad a penelitian ini menemukan bahwa non-performing financing dan biaya operasonal dan pendapatan operasional berpengaruh negatif dan signifikan terhadap tingkat bagi hasil deposito mudharabah. Namun financing to deposit ratio berpengaruh positif dan signifikan terhadap tingkat bagi hasil deposito mudharabah. Return on asset tidak memoderasi variabel non-performing financing dan financing to deposit ratio. namun memoderasi variabel biaya operasonal dan pendapatan operasional terhadap tingkat bagi hasil deposito mudharabah.

Kata kunci: Non-Performing Financing, Financing to Deposit Ratio, Biaya Operasonal dan Pend apatan Operasional, Tingkat Bagi Hasil Dep osito Mud harabah, Return on Asset

How to cite: Damayanti, A. E. R. I. ., \& Annisa, A. A. . (2021). Pengaruh NPF, FDR, dan BOPO terhadap tingkat bagi hasil deposito mudharabah: ROA sebagai variabel moderating. Journal of Accounting and Digital Finance, 1(1), 36-48.
\end{abstract}

\section{Pendahuluan}

Pada kenyataannya, Negara Indonesia sebagian besar penduduknya adalah seorang muslim. Dan tentu menjadi kemudahan bagi berkembangnya lembaga keuangan 
syariah di Indonesia. Perbankan menjadi institusi yang berperan penting dalam sistem ekonomi suatu negara, terutama bank syariah yang berada di negara dengan mayoritas penduduk muslim. Terbukti dengan berdirinya Bank Syariah pertama di negara Indonesia yaitu Bank Muamalat Indonesia, yang mengindikasikan bahwa perkembangan ekonomi Islam Indonesia sudah menuju keberhasilan nyata. Hal ini terbukti dari kesadaran masyarakat dalam menggunakan produk bank syariah seperti penghimpunan dana.

Mengacu pada laporan perkembangan keuangan syariah OJK, didapatkan informasi berikut:

Tabel 1. Pertumbuhan DPK Bank Umum Syariah 2015-2019

\begin{tabular}{lrrrrr}
\hline Keuangan BUS & \multicolumn{1}{c}{2015} & 2016 & 2017 & \multicolumn{1}{l}{2018} & 2019 \\
\hline DPK & $2,44 \%$ & $18,02 \%$ & $15,50 \%$ & $8,06 \%$ & $12,18 \%$ \\
Giro & $13,92 \%$ & $32,15 \%$ & $43,16 \%$ & $9,12 \%$ & $32,24 \%$ \\
Tabungan & $7,94 \%$ & $22,76 \%$ & $15,66 \%$ & $16,02 \%$ & $16,20 \%$ \\
Deposito & $4,23 \%$ & $13,73 \%$ & $18,13 \%$ & $9,12 \%$ & $5,59 \%$ \\
\hline
\end{tabular}

Sumber:OJK

Mengacu pada Tabel 1 menunjukkan terjadi peningkatan pertumbuhan DPK pada Bank Umum Syariah (BUS) yang tumbuh 12,18\% atau Rp 288,98 triliun sepanjang tahun 2019 , lebih tinggi dari tahun sebelumnya yaitu hanya $8,06 \%$. Namun seiring bertumbuhnya DPK pada Bank Umum Syariah, produk deposito mudharabah mengalami perlambatan yang hanya memiliki porsi sebesar $5,59 \%$, lebih rendah daripada tahun sebelum nya yaitu sebesar $9,12 \%$, sehingga perbankan syariah mulai mengerek nisbah bagi hasil. Tren penurunan imbal bagi hasil yang dilakukan oleh bank merupakan respon bank syariah atas kebijakan penurunan suku acuan oleh Bank Indonesia pada tahun lalu. Secara industri, OJK mencatat pada Oktober 2019, ekuivalen tingkat imbal hasil perbankan syariah tercatat sebesar 10,2\%, turun 51 basis poin dari tahun sebelumnya.

Presentase tingkat bagi hasil atau Indikasi rate of return pada produkpenghim pun dana bank syariah, memiliki banyak faktor yang dapat mempengaruhinya, yaitu bergantung pada tinggi rendahnya suatu bank dalam hal permodalan, tinggi rendahnya suatu bank dalam memeperoleh pendapatan, tinggi rendahnya suatu bank dalam memberikan pembiayaan, tingkat efisiensi suatu bank dalam mengelola usaha, serta kualitas asset suatu bank. Guna mempertahankan kualitas rate of return untuk nasabah, pengaruh dari faktor-faktor ini bagi lembaga bank syariah menjadi faktor yang penting (Isna, 2012:31).

Pada kontrak mudharabah, besar kecilnya perolehan tingkat bagi hasil dapat dipengaruhi oleh salah satu faktor yaitu, dapat dilihat dari tinggi rendahnya bank dalam memperoleh pendapatan. Profitabilitas menjadi indikator yang digunakan untuk melihat kinerja pada suatu lembaga serta kompetisi perusahaan tatkala mendatangkan keuntungan. Tingkat profitabilitas dalam perhitungannya menggunakan ROA atau rasio pengembalian asset, serta Biaya Operasional terhadap Pendapatan Operasional (BOPO). Sedangkan untuk mengetahui besar kecilnya 
tingkat pembiayaan terhadap dana pihak ketiga, maka dapat ditinjau dari tingkat FDR atau Financing to Deposits Ratio. Kemudian guna melihat efisiensi pengelolaan usaha pada bank dapat ditinjau dari tingkat Non-Performing Financing (NPF) atau permasalahan kredit (Antonio, 2001:145).

Pembiayaan yang tergolong tidak lancar atau Non-Performing Financing dapat menghambat pendapatan yang diperoleh bank syariah sebab tidak lunasnya pembiayaan dari pihak debitur. Apabila tingkat kredit macet atau NPF menunjukkan nilai yang tinggi, dapat menyebabkan tingkat profitabilitas rendah sehing ga perolehan bagi hasil yang diperoleh akan ikut menurun. Kemudian apabila tingkat kredit macet atau Non-Performing Financing (NPF) rendah, dapat menyebabkan profitabilitas tinggi yang berimbas pada perolehan bagi hasil yang diperoleh tinggi juga (Sari, 2017:2).

Penentuan tinggi rendahnyatingkat FDR diperoleh dari pembiayaan yang diberikan untuk nasabah yang dibandingkan dengan jumlah dana terhimpun seperti padaproduk giro, deposito, maupun tabungan. Kemudian kom ponen-komponen tersebut nantinya akan didapat jumlah pendistribusian dari bagi hasil pada setiap jenis dana yang dihimpun oleh bank. Apabila bank memiliki FDR tinggi, tentu bank berusaha dalam meningkatkan dana yang diperolehnya, seperti dengan deposito. Sehingga hal ini dapatmeningkatkan perolehan bagi hasil untuk nasabah. (Faza, 2018:8).

Untuk mengetahui besar kecilnya pendapatan bank, maka perlu dilakukan pengukuran guna melihat kinerja pada operasional bank, apakah sudah efisien atau belum yaitu dengan rasio BOPO. Pengukuran tersebut nantinya akan berguna untuk melihat seberapa besar return yang didapatkan nasabah dari deposito mudharabah (Rahayu, 2015:2).

Penting bagi bank dalam menjaga kinerjanya dengan baik. Indikator yang tepat guna menilai baik atau buruknya kinerja bank, dapat ditinjau berdasarkan perolehan labanya. Bank Indonesia sebagai pembimbing serta pengawas perbankan memilih nilai profitabilitas yang dinilai memakai ROA, hal ini dikarenakan ROA memfokuskan pada kemampuan perusahaan dalam mendatangkan laba yang dipakai guna melaksanakan opersional perusahaan dengan memanfaatkan asset produktif yang dimilikinya. Jadi apabila ROA memiliki nilai yang tinggi maka laba bank tersebut semakin tinggi pula (Dwi, 2016:102). ROA dipilih sebagai variabel moderating, guna mengetahui bagaimana ROA dapat memperkuat atau bahkan memperlemah variabel pada penelitian ini dalam mempengaruhi perolehan Bagi Hasil pada Deposito Mudharabah.

\section{Tinjauan Pustaka}

\section{Agency teory}

Teori keagenan yaitu teori yang menjabarkan suatu hubungan agentkepada principal (Anthony dan Govindarajan, 2005:269). Hubungan antara agent dan principal ini, adalah ketika shahibul mal memberi amanah untuk dikelola dananya kepada bank syariah. 


\section{Tingkat bagi hasil pada deposito mudharabah}

Bagi hasil dari Deposito Mudharabah merupakan bentuk return dari bank yang telah melakukan pembiayaan guna memperoleh keuantungan, yang dibagikan kepada nasabah atas penghimpunan dana nasabah pada produk deposito. Rumusnya ialah:

\section{NPF (Non-performing financing)}

$$
\text { Bagi hasil }=\frac{\text { Bagi hasil deposito mudharabah }}{\text { Volume deposito mudharabah }} \times 100 \%
$$

NPF adalah permasalahan pada pembiayaan, baik dalam kategori kolektibitas termasuk kriteria kurang lancar, diragukan bahkan sampai macet (Dendawijaya, 2009:82). Rumusnya ialah:

$$
N P F=\frac{\text { Jumlah pembiayaan bermasalah }}{\text { Total pembiayaan }} \times 100 \%
$$

\section{FDR (Financing to deposit ratio)}

FDR adalah perbandingan yang menunjukkan total keseluruhan pembiayaan yang dibagikan oleh bank dengan seberapa besar dana yang diperoleh oleh bank (Kasm ir, 2008:116). Rumusnya ialah:

$$
F D R=\frac{\text { Total Pembiayaan }}{\text { Dana Pihak Ketiga }} \times 100 \%
$$

\section{BOPO (Biaya operasional terhadap pendapatan operasional)}

BOPO yaitu suatu rasio antara beban operasional dengan pendapatan operasional (Dendawijaya, 2009:119). Rumusnya ialah:

ROA (Return on asset)

$$
B O P O=\frac{\text { Biaya Operasional }}{\text { Pendapatan Operasional }}
$$

ROA adalah suatu perbandingan yang memperlihatkan bagaimana kemampuan perusahaan dalam menggunakan aktivanya guna menghasilkan keuntungan (Darmadji, 2008:200). Rumusnya ialah:

$$
R O A=\frac{\text { Laba Sebelum Pajak }}{\text { Rata }- \text { rata Total Aset }} \times 100 \%
$$

\section{Pengaruh NPF terhadap tingkat bagi hasil deposito mudharabah}

Menurut penelitian Huruniang (2015) dan Rahmadhani (2017) memperoleh hasil bahwa NPF berdampaknegatif signifikan terhadap Tingkat Bagi Hasil pada Deposito Mudharabah.

H1: Semakin kuatNPF, semakin rendah tingkatbagi hasil deposito mudharabah

\section{Pengaruh FDR terhadap tingkat bagi hasil deposito mudharabah}

Menurut penelitian Syukur (2017) dan Faza (2018) memperoleh hasil bahwa FDR berdampak positif signifikan terhadap Tingkat Bagi Hasil pada Deposito Mudharabah. H2: Semakin kuat FDR, semakin tinggi tingkat bagi hasil deposito

\section{Pengaruh BOPO terhadap tingkat bagi hasil deposito mudharabah}

Menurutpenelitian hasil penelitian dari Wirawan (2016) dan Ayu (2016) diperoleh hasil bahwa BOPO berdampak negatif signifikan terhadap Tingkat Bagi Hasil pada Deposito Mudharabah.

H3: Semakin kuatBOPO, semakin rendah tingkat bagi hasil deposito mudharabah 
Pengaruh variabel independen terhadap variabel dependen dengan dimoderasi ROA

Menurut penelitian penelitian yang dilakukan oleh Ady Dwi Dhamayanti (2016) dan Amran Prasetya Nugraha (2018) menyatakan bahwa ROA mampu memoderasi variabel NPF, FDR, dan BOPO terhadap variabel Tingkat Bagi Hasil Deposito Mudharabah.

H4: ROA memoderasi hubungan antara NPF terhadap tingkat bagi hasil deposito mudharabah

H5: ROA memoderasi hubungan antara FDR terhadap tingkat bagi hasil deposito mudharabah

H6: ROA memoderasi hubungan antara BOPO terhadap tingkat bagi hasil deposito mudharabah

\section{Kerangka penelitan}

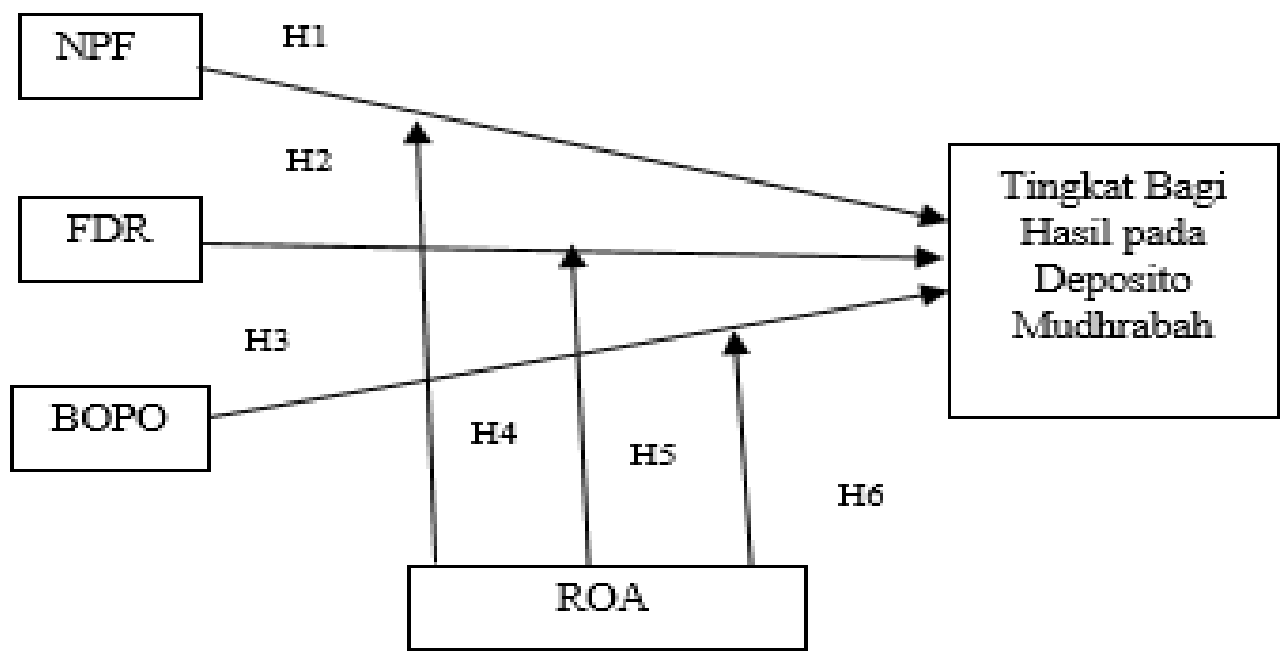

Gambar 1. Kerangka Konseptual Penelitian

\section{Metode Penelitian}

Penelitian ini merupakan jenis penelitian kuantitatif, dengan menggunakan teknik pengumpulan data melalui observasi tidak langsung. Populasi pada riset ini adalah Bank Umum Syariah di Indonesia yang sudah terdaftar di OJK yang berjumlah 14 bank. Teknik pemilihan sampel pada penelitian ini menggunakan purposive sampling dengan kriteria Bank Umum Syariah (BUS) yang sudah beroperasi dengan periode minimal tahun 2015 yang sudah terdaftar pada OJK, BUS yang situsnya sudah mempublikasikan laporan keuangan tahunan periode 2015 sampai 2019, serta memenuhi kelengkapan data, BUS yang menyediakan produk penghimpun dana deposito mudharabah berjangka 12 bulan. Sampel yang sesuai dengan kriteria berjumlah 9 bank, yaitu: Bank Muamalat Indonesia, Bank BRISyariah, Bank Jabar Banten Syariah, Bank Syariah Mandiri, Bank Syariah Bukopin, Bank Victoria Syariah, Bank BNI Syariah, Bank Panin Dubai Syariah, Bank Mega Syariah. Data dalam penelitian ini ialah data sekunder berupa annual report Bank Umum Syariah yang didapat dari website masing - masing bank yang terkait. Teknik analisis data dalam 
penelitian ini menggunakan analisis MRA (Moderated Regression Analisys). Persamaan regresi dalam penelelitian ini yaitu:

$$
\begin{aligned}
& Y=\alpha+\beta_{1} X_{1}+\beta_{2} X_{2}+\beta_{3} X_{3}+e \\
& Y=\alpha+\beta_{1} X_{1}+\beta_{2} X_{2}+\beta_{3} X_{3}+\beta_{1} X_{1} Z_{1}+\beta_{2} X_{2} Z_{2}+\beta_{3} X_{3} Z_{3}+e
\end{aligned}
$$

Dimana:

Y : variabel dependen (tingkatbagi hasil)

a : nilaikonstanta

b : nilaikoefisien variabel

X1 : NPF

$\mathrm{X} 2 \quad:$ FDR

X3 :BOPO

Z : ROA

e : error

\section{Hasil dan Pembahasan}

\subsection{Hasil penelitian}

Tabel 2. Hasil Uji Statistik Deskriptif

\begin{tabular}{lccccc}
\hline Keterangan & Y & NPF & FDR & BOPO & ROA \\
\hline Mean & 6,142000 & 5,360889 & 86,91578 & 100,0862 & $-0,037111$ \\
Median & 5,960000 & 4,430000 & 88,18000 & 96,02000 & 0,430000 \\
Maximum & 10,00000 & 22,04000 & 104,7500 & 217,4000 & 2,630000 \\
Minimum & 3,940000 & 1,720000 & 71,87000 & 81,26000 & $-10,77000$ \\
Std. Dev. & 1,355745 & 3,844258 & 8,327062 & 20,90039 & 2,416195 \\
Skewness & 1,056201 & 2,752429 & $-0,024160$ & 4,222995 & $-3,106952$ \\
Kurtosis & 3,822223 & 11,29508 & 2,052747 & 23,45982 & 12,71883 \\
\hline
\end{tabular}

Berdasarkan Tabel 2 rata - rata Variabel $\mathrm{Y}$ atau tingkat bagi hasil deposito mudharabah mempunyai mean yaitu 6.142 dengan std deviasi 1.355745. Variabel X1 atau NPF, mempunyai mean yaitu 5.360889 dengan std deviasi 3.844258. Variabel X2 atau FDR, mempunyai mean yaitu 86.91578dengan std deviasi 8.327062. Variabel X3 atau BOPO, mempunyai mean yaitu 100.0862 dengan std deviasi 20.90039 . Variabel Z atau ROA, mempunyai mean yaitu -0.037111 dengan std deviasi 2.416195 .

Tabel 3. Hasil Uji Determinasi $R^{2}$

\begin{tabular}{llll}
\hline \multicolumn{4}{c}{ Weighted Statistics } \\
\hline R-squared & 0,282191 & Mean dependent var & 6,142000 \\
Adjusted R-squared & 0,271370 & S.D. dependent var & 1,342254 \\
S.E. of regression & 1,145746 & Sum squared resid & 522,4680 \\
F-statistic & 26,07756 & Durbin-Watson stat & 1,126031 \\
Prob(F-statistic) & 0,000000 & & \\
\hline
\end{tabular}

Mengacu pada hasil uji regresi diatas didapatkan bahwa model regresi antara variabel independen dan independen memiliki nilai koefisien determinasi pada Adjusted $R$ Square ialah 0,271370. Yang artinya variabel independen bisa mempengaruhi variabel dependen sebasar $27,137 \%$. Sedangkan $72,863 \%$ dipengaruhi variabel independen lain yang belum terdapat pada penelitian ini. 
Nilai f tabel ditemukan sebesar 2,61 pada tingkat signifikansi 0,05 atau $5 \%$. Mengacu pada tabel diatas mengenai hasil uji regresi memperoleh hasil bahwa nilai koefisien sebesar 26,07756 > F tabel dengan Prob(F-statistic) $<0,05$ yaitu 0,000000. Dapat diambil kesimpulan bahwavariabel independen pada riset ini memiliki penganuh terhadap variabel dependen

Tabel 4. Hasil Uji T

\begin{tabular}{lrrrl}
\hline \multicolumn{1}{c}{ Variabel } & Koefisien & Std. Error & t- hitung & Prob. \\
\hline Konstanta & 4,565081 & 1,295957 & 3,522556 & 0,0005 \\
NPF & $-0,062932$ & 0,044848 & 1,403234 & 0,1613 \\
FDR & 0,005606 & 0,008072 & 0,694420 & 0,4878 \\
BOPO & $-0,012384$ & 0,015533 & 0,797275 & 0,4258 \\
NPF*ROA & 0,067479 & 0,009703 & 6,954558 & 0,0000 \\
FDR $^{*}$ ROA & 0,011236 & 0,001400 & 8,024395 & 0,0000 \\
BOPO* $^{*}$ ROA & 0,001150 & 0,001217 & 0,944493 & 0,3455 \\
\hline
\end{tabular}

Nilai t tabel bernilai 1,68 dengan 0,05 atau 5\% sebagai tingkat signifikansinya. Hasil uji regresi tabel diatas memutuskan bahwa:

1. Variabel NPF menunjukkan nilai t hitung $1,403234<\mathrm{t}$ tabel dengan nilai prob 0,1613>0,05 dengan koefisien negatif. Sehingga dapat disimpulkan NPF secara parsial berpengaruh negatif dan signifikan terhadap tingkat bagi hasil deposito mudharabah.

2. Variabel FDR menunjukkan nilai t hitung $0,694420<\mathrm{t}$ tabel dengan nilai prob $0,4878>0,05$ dengan koefisien positif. Sehingga dapat disimpulkan FDR secara parsial berpengaruh positif dan signifikan terhadap tingkat bagi hasil deposito mudharabah.

3. Variabel BOPO menunjukkan nilai thitung $0,797275<\mathrm{t}$ tabel dengan nilai prob 0,4258>0,05 dengan koefisien negatif. Sehingga dapat disimpulkan BOPO secara parsial berpengaruh negatif dan signifikan terhadap tingkat bagi hasil deposito mudharabah.

4. Variabel NPF yang dimoderasi oleh ROA menunjukkan nilai thitung 6,954558 >t tabel dengan nilai prob $0,0000<0,05$ dengan koefisien positif. Sehingga dapat disimpulkan NPF yang dimoderasi oleh ROA tidak berpengaruh terhadap tingkat bagi hasil deposito mudharabah.

5. Variabel FDR yang dimoderasi oleh ROA menunjukkan nilai thitung 8,024395 >t tabel dengan nilai prob $0,0000<0,05$ dengan koefisien positif. Sehingga dapat disimpulkan FDR yang dimoderasi oleh ROA tidak berpengaruh terhadap tingkat bagi hasil deposito mudharabah.

6. Variabel BOPO yang dimoderasi oleh ROA menunjukkan nilai thitung 0,944493< t tabel dengan nilai prob 0,3455 > 0,05 dengan koefisien positif. Sehingga dapat disimpulkan bahwa BOPO yang dimoderasi oleh ROA berpengaruh positif dan signifikan terhadap tingkat bagi hasil deposito mudharabah.

\section{Analisis MRA (Moderated Regression Analisys)}

Model regesi linear berganda yang diperoleh dari pengujian adalah sebagai berikut:

$$
\begin{aligned}
Y= & \alpha+\beta_{1} X_{1}+\beta_{2} X_{2}+\beta_{3} X_{3}+\beta_{4} X_{1} Z+\beta_{5} X_{2} Z+\beta_{6} X_{3} Z+e \\
Y= & 4,565081-\left(0,062932 X_{1}\right)+\left(0,005606 X_{2}\right)-\left(0,012384 X_{3}\right)+ \\
& \left(0,067479 X_{1} Z\right)+\left(0,011236 X_{2} Z\right)+\left(0,001150 X_{3} Z\right)
\end{aligned}
$$


Penjelasan dari persamaan di atas yakni:

a. Konstanta didapatkan 4,565081 memiliki arti bahwa, apabila variabel independen sama dengan nol (0), artinya tingkat bagi hasil deposito mudharabah $(Y)$ akan meningkat sejum lah 4,565081.

b. Koefisien regresi variabel NPF diperoleh $-0,062932$ searah koefisien negatif, artinya apabila variabel NPF bertam bah besar 1 satuan dengan ketentuan variabel lainnya stabil maka tingkat bagi hasil deposito mudharabah akan turun sebesar 0,062932 .

c. Koefisien regresi variabel FDR diperoleh 0,005606 searah koefisien positif, artinya apabila variabelFDR bertambah besar 1 satuan dengan ketentuan variabel lainnya stabil maka tingkat bagi hasil deposito mudharabah akan meningkat sebesar 0,005606 .

d. Koefisien regresi variabel BOPO diperoleh -0,012384 searah koefisien negatif, artinya apabila variabel BOPO bertambah besar 1 satuan dengan ketentuan variabel lainnya stabil maka tingkat bagi hasil deposito mudharabah akan turun sebesar 0,012384.

e. Koefisien regresi variabel NPF yang dimoderasi oleh ROA diperoleh 0,067479 searah koefisien positif, artinya apabila variabel NPF yang dimoderasi oleh ROA bertambah besar 1 satuan dengan ketentuan variabel lainnya stabil maka tingkat bagi hasil deposito mudharabah akan meningkat sebesar 0,067479.

f. Koefisien regresi variabel FDR yang dimoderasi oleh ROA diperoleh 0,011236 searah koefisien positif, artinya apabila variabel FDR yang dimoderasi oleh ROA bertambah besar 1 satuan dengan ketentuan variabel lainnya stabil maka tingkat bagi hasil deposito mudharabah akan meningkat sebesar 0,011236.

g. Koefisien regresi variabel BOPO yang dimoderasi oleh ROA diperoleh 0,001150 searah koefisien positif, artinya apabila variabel BOPO yang dim oderasi oleh ROA bertambah besar 1 satuan dengan ketentuan variabel lainnya stabil maka tingkat bagi hasil deposito mudharabah akan meningkat sebesar 0,001150.

\subsection{Pembahasan}

\section{Pengaruh NPF terhadap tingkat bagi hasil deposito mudharabah}

Bersumber dari uji regresi linier berganda, nilai coefficient variabel NPF ialah 0,062932 dengan probabilitas sebesar 0,1613 yang memperlihatkan $>0,05$ atau lebih dari nilai signifikansinya. Ditarik kesimpulan bahwa hipotesis 1 diterima, dan dapat dikatakan bawa NPF memiliki pengaruh negatif dan signifikan terhadap Tingkat Bagi Hasil pada Deposito Mudharabah. Hasil riset ini sejalan dengan riset Laudia Huruniang \& Noven Suprayogi (2015) dan pada riset Lydia Rahmadani Arfiani \& Ade Sofyan Mulazid (2017).

Hasil penelitian yang dilakukan dapat dinyatakan bahwa rendah atau tingginya tingkat bagi hasil dapat dipengaruhi oleh NPF. Apabila nilai NPF pada suatu bank tinggi, maka mengindikasikan bahwa bank tersebut tidak sehat, sebab NPF mencerm inkan seberapa besar risiko kredityang nantinya akan ditanggung. Semakin besar nilai NPF pada suatu bank, tentu risiko kredit tertanggung juga besar nilainya, 
sehingga akan berimbas pada hilangnya peluang bagi bank guna mendapatkan pendapatan dari pembiayaan yang telah diberikan. Tentu hal ini sangat berpengaruh terhadap bank dalam mendapatkan keuntungan serta rentabilitas suatu bank juga menjadi buruk, sehingga perolehan bagi hasil dari bank juga menjadi rendah akibat terdampak dari nilai NPF ini.

\section{Pengaruh FDR terhadap tingkat bagi hasil deposito mudharabah}

Bersumber dari uji regresilinier berganda, nilai coefficientvariabelFDR ialah 0,005606 dengan probabilitas sebesar 0,4878 yang mem perlihatkan $>0,05$ atau lebih dari nilai signifikansinya. Ditarik kesimpulan bahwa hipotesis 2 diterima, dan dapat dikatakan bawa FDR memiliki pengaruh positif dan signifikan terhadap Tingkat Bagi Hasil pada Deposito Mudharabah. Hasil riset ini sejalan dengan riset Muhammad Syukur (2017) dan Zulfikar Faza \& Ummiy Fauziyah Lily (2018).

Hasil penelitian yang dilakukan dapat dinyatakan bahwa rendah atau tingginya perolehan bagi hasil dapat ditentukan oleh FDR. Apabila nilai FDR pada suatu bank tinggi, maka secara otomatis bank akan melakukan kegiatan yang berpotensi pada perolehan dana. Sehingga untuk menarik minat menghimpun dana di bank, perlu adanya jaminan yang menarik bagi nasabah seperti tingkat bagi hasil. Jadi dengan meningkatannya nilai FDR, akan berimbas pada return dari bagi hasil juga akan mengalami peningkatan.

\section{Pengaruh BOPO terhadap tingkat bagi hasil deposito mudharabah}

Bersumber dari uji regresi linier berganda, nilai coefficient variabel BOPO ialah 0,012384 dengan probabilitas sebesar 0,4258 yang memperlihatkan >0,05 atau lebih dari nilai signifikansinya. Ditarik kesimpulan bahwa hipotesis 3 diterima, dan dapat dikatakan bawa BOPO memiliki pengaruh negatif dan signifikan terhadap Tingkat Bagi Hasil pada Deposito Mudharabah. Hasil riset ini sejalan dengan riset Adhi Wirawan (2016).

Hasil penelitian yang dilakukan dapat dinyatakan bahwa rendah atau tingginya tingkat bagi hasil dapat dipengaruhi oleh BOPO. Apabila biaya operasional pada suatu bank nilainya rendah namun pendapatan operasionalnya tetap, maka dalam keadaan ini nilai BOPO rendah. Kemudian ketika biaya operasional tetap namun pendapatan operasionalnya meningkat, maka keadaan ini disebut juga nilai BOPO rendah. Menurunnya nilai BOPO ini menunjukkan bahwa bank dalam mengeluarkan biaya semakin efisien, seperti dalam bentuk investasi pembiayaan guna memperoleh pendapatan yang maksimal. Dengan meningkatnya pendapatan pada bank ini, tentu berimbas pada peningkatan perolehan bagi hasil untuk nasabah. Jadi apabila nilai BOPO turun, bagi hasil yang diterima nasabah akan tinggi nilainya.

\section{Pengaruh NPF terhadap tingkat bagi hasil deposito mudharabah dengan dimoderasi oleh roa}

Bersumber dari uji regresi linier berganda, nilai coefficient variabel NPF $\left(\mathrm{X}_{1}\right)$ yang dimoderasi oleh ROA (Z) ialah 0,067479 dengan probabilitas sebesar 0,0000 yang memperlihatkan $<0,05$ atau kurang dari nilai signifikansinya. Ditarik kesimpulan bahwa hipotesis 4 ditolak, dan dapat dikatakan bawa NPF $\left(X_{1}\right)$ yang dimoderasi oleh ROA (Z) tidak memiliki pengaruh terhadap Tingkat Bagi Hasil pada Deposito 
Mudharabah atau tidak dapat memoderasi hubungan antara variabel independen dengan dependen. Hasil penelitian yang dilakukan dapat dinyatakan bahwa dengan adanya ROA tidak dapat memperkuat hubungan antara NPF dengan Tingkat Bagi Hasil pada Deposito Mudharabah.

\section{Pengaruh FDR terhadap tingkat bagi hasil deposito mudharabah dengan} dimoderasi oleh ROA

Bersumber dari uji regresi linier berganda, nilai coefficient variabel FDR $\left(\mathrm{X}_{2}\right)$ yang dimoderasi oleh ROA (Z) ialah 0,011236 dengan probabilitas sebesar 0,0000 yang memperlihatkan $<0,05$ atau kurang dari nilai signifikansinya. Ditarik kesimpulan bahwa hipotesis 5 ditolak, dan dapat dikatakan bawa FDR (X2) yang dimoderasi oleh ROA (Z) tidak memiliki pengaruh terhadap Tingkat Bagi Hasil pada Deposito Mudharabah atau tidak dapat memoderasi hubungan antara variabel independen dengan dependen. Hasil penelitian yang dilakukan dapat dinyatakan bahwa dengan adanya ROA tidak dapat memperkuat hubungan antara FDR dengan Tingkat Bagi Hasil pada Deposito Mudharabah.

Pengaruh BOPO terhadap tingkat bagi hasil deposito mudharabah dengan dimoderasi oleh ROA

Bersumber dari uji regresi linier berganda, nilai coefficient variabel $\mathrm{BOPO}\left(\mathrm{X}_{3}\right)$ yang dimoderasi oleh ROA (Z) ialah 0,001150 dengan probabilitas sebesar 0,3455 yang memperlihatkan $>0,05$ atau lebih dari nilai signifikansinya. Ditarik kesimpulan bahwa hipotesis 6 diterima, dan dapat dikatakan bawa BOPO $\left(\mathrm{X}_{3}\right)$ yang dimoderasi oleh ROA (Z) memiliki pengaruh terhadap Tingkat Bagi Hasil pada Deposito Mudharabah atau dapat memoderasi hubungan antara variabel independen dengan dependen. Hasil penelitian yang dilakukan dapat dinyatakan bahwa dengan adanya ROA dapat memperkuat hubungan antara BOPO dengan Tingkat Bagi Hasil pada Deposito Mudharabah.

\section{Kesimpulan}

Non-Performing Financing dan Biaya Operasonal dan Pendapatan Operasional berpengaruh negatif dan signifikan terhadap tingkatbagi hasil deposito mudharabah. Namun Financing to DepositRatio berpengaruh positif dan signifikan terhadap tingkat bagi hasil deposito mudharabah. Return on Asset tidak memoderasi variabel NonPerforming Financing dan Financing to Deposit Ratio. Namun memoderasi variabel Biaya Operasonal dan Pendapatan Operasional terhadap tingkat bagi hasil deposito mudharabah

\section{Ucapan Terimakasih}

Ucapan terimakasih pen eliti sampaikan terutama kepada para pimpinan, dosen dan staff di Fakultas Ekonomi dan Bisnis Islam IAIN Salatiga yang telah memberikan bekal berbag ai teori, ilmu peng etahuan dan peng alaman yang sangat bermanfaat bagi peneliti, dan semua pihak yang tidak dapat disebutkan satu persatu, yang sudah membantu peneliti dalam menyelesaikan penelitian ini. 


\section{Referensi}

Amelia, Rizky. 2011. Pengaruh CAR, FDR dan NPF Terhadap Return Bagi Hasil Deposito Mudharabah Pada Perbankan Syariah. Skripsi:UIN Syarif Hidayatullah Jakarta.

Anthony dan Govindarajan. 2005. Manajement Control System. Jakarta: Salemba Empat.

Antonio, Muhammad Syafi'i. 2001. Bank Syariah: dari Teori ke Praktik. Cetakan ke-1. Jakarta: Gema Insani Press

Apriandika, Rangga. 2011. Analisis hubungan kinerja keuangan terhadap tingkatbagi hasil simpanan mudharabah pada bank syariah. Jurnal. Universitas Lampung.

Aprilia, Miranti Saputri. 2018. Analisis Pengaruh Kinerja Keuangan dan Suku Bunga Terhadap Tingkat Bagi Hasil Deposito Mudharabah Pada Perbankan Syariah Di Indonesia Periode Tahun 2011-1 Sampai 2017-10. Skripsi: Universitas Islam Indonesia.

As-Sirjani, Raghib. 2011. Sumbangan Peradapan Islam pada Dunia. Jakarta: Pustaka Al-Kautsar.

Ayu, Putri Rahayu dan Bustamam.2016. Pengaruh Return On Asset,Bopo Dan Suku Bunga Terhadap Tingkat Bagi Hasil Deposito Mudharabah Bank Umum Syariah. Jurnal IImiah Mahasiswa Ekonomi Akuntansi (JIMEKA) Vol. 1, No. 1

Bawono, A. dan, Fendha, A., \& Shina, I. (2018). Ekonometrika Terapan Untuk Ekonomi dan Bisnis Islam. Salatiga: LP2M IAIN Salatiga.

Boediono \& Wayan Koster M. 2001. Teori Aplikasi Statistika dsn Probabilitas. Bandung: PT Remaja Rosdakarya

Darmadji, Tjiptono \& Hendry M. Fakhruddin. 2008. Pasar Modal di Indonesia.Pendekatan Tanya Jawab. Edisi 2. Jakarta : Salem ba Empat.

Dendawijaya, Lukman. 2009. Manajemen Perbankan. Edisi 2. Cetakan ke 2. Jakarta: Ghalia Indonesia.

Dwi, Ady Dhamayanti, 2016. Pengaruh Non Performing Financing dan Financing to Deposit Ratio terhadap Tingkat Bagi Hasil Deposito Mudharabah dengan Retum On Asset sebagai Variabel Moderasi (Studi Kasus pada Bank Umum Syariah), Skripsi. STIE Perbanas Surabaya.

Fahrurrozi. 2016. Konsep Perjanjian Profita and Loss sharing dalam Ekonomi Islam. Jurnal Ekonomi dan Perbankan SyariahP-ISSN:2354-7057; E-ISSN:2442-3067. Vol. 3, No. 2.

Faza, Zulfikar dan Ummiy Fauziyah Laily. 2018. Pengaruh Return On Asset, Retum On Equity, Dan Financing To Deposit Ratio Terhadap Tingkat Bagi Hasil Deposito Mudharabah. Jurnal eL Qist: Vol. 08, No. 01.

Ghozali, Imam. 2013. Aplikasi Analisis Multivariate dengan Program IBM SPSS 21. Edisi Ketujuh. Semarang:Badan Penerbit Universitas Diponegoro.

Giannini, Nur Gilang. 2013. Faktor yang Mempengaruhi Pembiayaan Mudharabah pada Industri Perbankan Syariah di Indonesia Periode 2011-2014. JESTT. Vol. 2, No. 7 
Huruniang, Lauda dan Noven Suprayogi. 2015. Variabel-Variabel Yang Mempengaruhi Tingkat Bagi Hasil Tabungan Mudharabah Pada Industri Perbankan Syariah Di Indonesia Periode 2011-2014. JESTT Vol. 2 No. 7

Indriyani, Feby Enggar. 2020. Pengaruh Dana Pihak Ketiga dan Rasio Keuangan terhadap Bagi Hasil Mudharabah dengan Return on Asset sebagai Variabel Moderating Pada Bank Syariah (2015-2019). Skripsi: Institut Agama Islam Negeri Salatiga.

Irkhami, Nafis. 2016. Islamic Ethical Investment: Membincang Aspek Hukum dan Ekonomi Syariah. Salatiga:LP2M-Press IAIN Salatiga

Isna, Andryani dan Kunti Sunaryo. 2012. Analisis Pengaruh Return on Asset, BOPO, Dan Suku Bunga terhadap Tingkat Bagi Hasil Deposito Mudharabah pada Bank Umum Syariah. Jurnal Ekonomi dan Bisnis. 11(1).

Kasmir, 2008. Manajemen Perbankan. Edisi 1. Cetakan ke 5. Jakarta: PT Raja Grafindo Persada.

Muham mad. 2002. Manajemen Bank Syariah. Yogyakarta: UPP AMP YKPN

Nofianti, Nana dkk. 2015. Analisis Pengaruh ROA, BOPO, Suku Bunga, FDR dan NPF terhadap Tingkat Bagi Hasil Deposito Mudharabah (Studi Empiris pada Bank Umum Syariah di Indonesia Tahun 2011-2013). Esensi. Jurnal Bisnisdan Manajemen. Vol. 5, No. 1, April 2015.

Prasetya, Amran Nugraha. 2018. Analisis Pengaruh BOPO, CAR, NPF, FDR dan Inflasi Terhadap Tingkat Bagi Hasil Deposito Mudharabah dengan Roa Sebagai Variabel Moderasi Pada Bank Umum Syariah. Skripsi. STIE Perbanas Surabaya.

Pratiwi, Nissa Widarto. 2019. Analisis ROA, CAR, FDR, dan BOPO terhadap Tingkat Bagi Hasil Deposito Mudharabah Pada Bank Umum Syariah Skripsi. Surabaya (ID): STIE Perbanas Surabaya.

Rahayu, S. 2015. Pengaruh Return on Asset, BOPO, Suku Bunga dan Capital Adequacy Ratio terhadap Tingkat Bagi Hasil Deposito Mudharabah Pada Perbankan Syariah. Journal Of Accounting. Vol. 01. N0. 01.

Rahmadhani, Lydia Arfiani dan Ade Sofyan Mulazid. 2017. Analisis Faktor-Faktor Yang Mempengaruhi Tingkat Bagi Hasil Simpanan Mudharabah Pada Bank Umum Syariah Indonesia Studi Kasus Pada Bank Umum Syariah Di Indonesia Periode 2011-2015. Iqtishadia: Jurnal Ekonomi dan Perbankan Syariah. Vol. 4 No. 1

Rahmawaty dan Yudina, Tiffany Andari. 2015. Pengaruh Return On Asset (ROA) dan Financing To Deposit Ratio (FDR) terhadap Tingkat Bagi Hasil Deposito Mudharabah pada Bank Umum Syariah. Jurnal Dinamika Akuntansi dan Bisnis. Vol. 2, No. 1, Maret 2015.

Sabtatianto, Reandy dan Muhamad Yusuf. 2018. Pengaruh BOPO, CAR, FDR dan ROA terhadap Tingkat Bagi Hasil Deposito Mudharabah pada Bank Umum Syariah di Indonesia (Studi Pada Bank Umum Syariah Di Indonesia). Jurnal IImu Akuntansi. 10(2): 169-186.

Sari, Maulita dkk. 2017. Pengaruh Non Performing Financing, Dana Pihak Ketiga, dan Inflasi Terhadap Tingkat Bagi Hasil Deposito Mudharabah. JRMA (Jurnal Riset Mahasiswa Akuntansi), Volume 5, No, 1 April 2017. 
Sofiyani, Iryana. 2017. Analisis Pengaruh ROA, BOPO, FDR, CAR dan NPF terhadap Tingkat Bagi Hasil Deposito Mudharabah dengan Profitabilitas sebagai variabel Moderating pada Bank Umum Syariah Indonesia Tahun 2012-2016. Skripsi: Institut Agama Islam Negeri Salatiga.

Sugiyono. 2017. Statistika Untuk Penelitian. Bandung:Alfabeta

Sujarweni, Wiratna. 2017. Analisis Laporan Keuangan: Teori, Aplikasi, dan Hasil Penelitian. Yogyakarta: Pustaka Baru Press.

Syukur, Muhammad. 2017. Pengaruh Rerturn On Assets, Financing To Deposit Ratio, BOPO Terhadap Tingkat Bagi Hasil Deposito Mudharabah (Studi pada PT. Bank Muamalat Indonesia, PT. Bank Syariah Mandiri, dan PT. Bank Bri Syariah Tahun 2010-2014).Skripsi. Surakarta (ID): Institut Agama Islam Negeri Surakarta.

Umiyati dan Shella Muthya Syarif. 2016. Kinerja Keuangan dan Tingkat Bagi Hasil Deposito Mudharabah pada Bank Umum Syariah Di Indonesia. Jurnal Akuntansi dan Keuangan Islam Vol. 4, No. 1

Winarno, Wing Wahyu. 2009. Analisis Ekonometrika dan Statistika dengan Eviews. Edisi Kedua. UPP STIM YKPN. Yogyakarta.

Wirawan, Adhi. 2016. Pengaruh ROA, ROE, Dan BOPO Terhadap TingkatBagi Hasil Deposito Mudharabah Pada Bank Umum Syariah. Skripsi: STIE Perbanas Surabaya.

Yoolanda, Alfan Harahap. 2017. Pengaruh CAR, NPFdan FDR Terhadap Return Bagi Hasil Deposito Mudharabah Pada Perbankan Syariah di Indonesia Periode 2012 - 2016 dengan Profitabilitas Sebagai Variabel Moderating. Skripsi. Medan (ID): Uneversitas Sumatera Utara.

Yudiana, Fetria Eka. 2014. Manajemen Pembiayaan Bank Syariah. Salatiga: STAIN Salatiga Press. 